$\int||$\begin{tabular}{c} 
JURNAL MEGA AKTIVA \\
$\begin{array}{c}\text { Email : } \text { megaaktiva@febi.umkendari.ac.id } \\
\text { Website }: \text { https://megaaktiva.umkendari.ac.id/index.php/Jurnal }\end{array}$ \\
\hline
\end{tabular}

\title{
ANALISIS PELAYANAN PUBLIK YANG PRO POOR PADA PENYEDIAAN AIR BERSIH PERPIPAAN
}

\author{
${ }^{1}$ Syamsir Nur, ${ }^{2}$ Muh. Armawaddin, ${ }^{3}$ Syamsul Anam \\ ${ }^{1}$ Fakultas Ekonomi dan Bisnis Universitas Halu Oleo \\ Kendari, Sulawesi Tenggara \\ ${ }^{2}$ Fakultas Ekonomi dan Bisnis Universitas Halu Oleo \\ Kendari, Sulawesi Tenggara \\ ${ }^{3}$ Fakultas Ekonomi dan Bisnis Universitas Halu Oleo \\ Kendari, Sulawesi Tenggara
}

\begin{abstract}
ABSTRAK
Target luaran yang ingin dicapai dalam penelitian ini adalah publikasi hasil penelitian pada jurnal ilmiah nasional, disampaikan pada dalam bentuk makalah pada temu ilmiah lokal dan nasional serta bahan ajar untuk pengembangan mata kuliah sehingga memberikan kontribusi yang penting pada ilmu pengetahuan. Penelitian ini difokuskan pada penyedia layanan dan pengguna layanan PDAM Kota Kendari dan PDAM Kabupaten Kolaka. Pemilihan informan penyedia layanan dan responden pengguna layanan dilakukan secara purposive sampling. Penyedia layanan adalah direktur atau jajaran pimpinan PDAM Kota Kendari dan Kabupaten Kolaka sebagai informan kunci, sedangkan pengguna layanan adalah pelanggan rumah tangga sebanyak 100 orang dengan kriteria pelanggan golongan rumah tangga yang mengkonsumsi air pada kategori Blok I $\left(0-20 \mathrm{M}^{3}\right)$. Analisis data dilakukan dengan metode desksriptif kuantitatif. Hasil penelitian diperloeh bahwa kinerja PDAM di Sulawesi Tenggara dalam melakukan pelayanan publik di pengaruhi oleh kondisi pembiayaan infrastruktur yang dimilkiki serta penerapan terhadap prinsip-prinsip corporate governance dalam mengelola dan menyediakan air bersih perpipaan. Selain itu diperoleh pula bahwa pelayanan publik (public service) yang dilakukan PDAM dalam mengelola dan menyediakan air bersih perpipaan berdampak terhadap pelayanan yang pro poor. Adanya persoalan pada kualitas pelayanan dan cakupan pelayanan berdampak terhadap kemampuan PDAM dalam menghasilkan air bersih perpipaan cenderung tidak pro poor (tidak dapat meningkatkan akses dan keterjangkauan) pelayanan air bersih. Public service PDAM yang baik akan menciptakan terpenuhinya kebutuhan air bersih bagi masyarakat yang mudah, murah dan terjangkau.
\end{abstract}

\section{Kata Kunci: Pelayanan Publik, Air Bersih, Pro Poor}

\section{PENDAHULUAN}

Pemenuhan akan kebutuhan air bersih merupakan salah satu jenis pelayanan dasar yang harus disediakan oleh pemerintah daerah. Ketidakcukupan air bersih akan berdampak pada aspek ekonomi dan sosial bagi masyarakat, terutama bagi kelompok masyarakat yang berpendapatan rendah. Mungkasa (2006) mengungkapkan bahwa 
ketika penduduk perkotaan memiliki akses air bersih yang terbatas maka akan berujung pada penurunan kualitas hidup, pengurangan produktivitas, penambahan biaya kesehatan dan polusi lingkungan yang tak terhindarkan, yang keseluruhannya mengarah pada peningkatan kemiskinan di perkotaan. Munif (2012) juga menegaskan bahwa rendahnya tingkat akses terhadap air bersih di Indonesia dipengaruhi oleh buruknya pengelolaan lingkungan, persoalan pembiayaan infrastruktur air bersih serta lemahnya kapasitas penyedia layanan air bersih.

Seperti kita ketahui bahwa saat ini tanggung jawab penyediaan layanan air bersih oleh pemerintah daerah umumnya dikelola melalui Badan Usaha Milik Daerah (BUMD) oleh Perusahaan Daerah Air Minum (PDAM). Pengelolaan melalui badan usaha menunjukkan bahwa adanya pelibatan (manajemen) pihak swasta dalam penyelenggaraan layanan publik yang ditujukan untuk memenuhi kebutuhan publik di sektor air bersih sebagai service delivery. Villaverde A. Ruiz et al (2013), mengungkapkan bahwa penggabungan pola pelayanan (campuran) merupakan opsi untuk menggabungkan keuntungan dari kepemilikan publik dan manajemen swasta, meskipun pendapat lain menyatakan bahwa penggabungan manajemen perusahaan secara signifikan dapat menimbulkan konflik internal antara kepentingan publik dan kepentingan pribadi manajer (Cruz dan Marques, 2012).

Pelayanan air bersih yang dikelola oleh badan usaha yang cenderung menciptakan "konflik kepentingan" memerlukan pendekatan pengelolaan yang harus dikendalikan dan diawasi dengan penuh kepatuhan kepada berbagai peraturan dan ketentuan yang berlaku. Hal ini dimaksudkan agar pengelolaan badan usaha dilakukan secara terbuka, responsif dan akuntabel. Berbagai fakta yang terkait dengan penyediaan air bersih yang dilakukan oleh PDAM di beberapa daerah menunjukkan permasalahan dalam hal pelayanan terutama aspek kualitas, kuantitas, kontinuitas air maupun keandalan sistem penyediaan sehingga pengelolaan layanan air bersih oleh pemerintah daerah tidak efisien dan bias terhadap penduduk miskin.

Peneliti memandang bahwa diperlukan pengelolaan badan usaha dalam perspektif corporate governance untuk mengatasi konflik kepentingan antara pihak pemerintah atau regulator (prinsipal) yang berkepentingan terhadap pelayanan publik dan pihak PDAM atau operator (agen) sebagai entitas bisnis. Penerapan corporate governence pada public governence dalam layanan air bersih mensyaratkan sinergitas yang mendorong penyediaan layanan yang berorientasi pada kepentingan publik (public service) berupa ketersediaan dan akses air bersih bagi masyarakat terutama kelompok masyarakat miskin (poor).

Telah menjadi kesepakatan pula bahwa peningkatan akses air bersih dapat menjadi jalan menuju penanggulangan kemiskinan. Dikaitkan dengan kondisi Sulawesi Tenggara, penyediaan layanan air bersih yang pro poor merupakan suatu keniscayaan, dengan berbagai pertimbangan diantaranya tingkat urbanisasi yang mengarah pada peningkatan jumlah penduduk miskin yang relatif tinggi serta proporsi penduduk miskin yang belum terlayani oleh air minum perpipaan melalui PDAM masih cukup besar. Oleh karenanya, penelitian ini dirumuskan dalam dua permasalahan utama yaitu: (1) bagaimana kinerja PDAM di Sulawesi Tenggara dalam melakukan pelayanan publik (2) apakah penyediaan air bersih oleh PDAM di Sulawesi Tenggara menghasillkan pelayanan publik yang pro poor. 


\section{KAJIAN TEORITIS}

\section{Konsep Air Bersih}

Air bersih dalam kehidupan manusia merupakan salah satu kebutuhan paling esensial, yang harus tersedia dalam kuantitas yang cukup dan kualitas yang memenuhi syarat dan terjamin kontinuitasnya. Selain untuk dikonsumsi air bersih juga dapat dijadikan sebagai salah satu sarana dalam meningkatkan kesejahteraan hidup melalui upaya peningkatan derajat kesehatan (Hakim, 2010). Penyediaan air bersih dengan jumlah yang terbatas disertai kualitas yang buruk akan mengakibatkan munculnya dampak ekonomi maupun non ekonomi bagi masyarakat. Karenanya air yang bersih, sehat dan produktif bagi masyarakat dijamin keberadaannya oleh pemerintah.

Pemenuhan air bersih di saat ini dilakukan melalui dua sistem penyediaan yaitu sistem perpipaan dan sistem non perpipaan. Namun, persoalan aksesibilitas masih menjadi masalah bagi sebagian pemerintah daerah. Aksesibilitas dapat dikatakan sebagai derajat hubungan antar satu tempat ke tempat lain yang dapat diukur dengan jumlah, biaya, jarak dan waktu. Tempat yang dapat dicapai dengan jarak yang pendek, waktu yang cepat, biaya yang rendah dan jumlah yang sesuai keinginan untuk mendapatkan air bersih menggambarkan adanya aksesibilitas yang tinggi. Apabila pemakai (konsumen) sulit untuk mendapatkan air bersih karena jarak yang jauh, waktu yang lama, biaya yang tinggi dan mendapatkan jumlah tidak sesuai yang diharapkan menggambarkan adanya aksesibilitas yang rendah (Hakim, 2010). Karena semakin jauh masyarakat mengakses air bersih berarti semakin buruk akses air bersih bagi masyarakat tersebut (Howard and Jamie, 2003).

\section{Konsep Pelayanan Publik}

Suryokusumo (2008) mengungkapkan bahwa kinerja pelayanan publik sangat terkait dengan keberhasilan mencapai tahapan dari proses peningkatan pelayanan kepada masyarakat yang diwujudkan dalam milestone keberhasilan. Dalam kaitan dengan pelayanan publik, maka pemerintah merupakan pihak yang paling bertanggungjawab menyediakan layanan tersebut. Pemerintah pada hakekatnya mengemban tiga fungsi utama yaitu fungsi distribusi, fungsi stabilisasi dan fungsi alokasi. Fungsi distribusi dan fungsi stabilisasi pada umumnya lebih efektif dan tepat dilaksanakan oleh pemerintah pusat. Sedangkan fungsi alokasi dilaksanakan oleh pemerintah daerah yang lebih mengetahui kebutuhan, kondisi dan situasi masyarakat setempat (Prawoto, 2011).

Pelayanan publik berdasarkan UU No. 25 tahun 2010 ditentukan atas dasar kriteria antara lain: karakteristik penyedia, sumber pembiayaan, ukuran besarnya biaya dan luas jangkauan. Dalam pelaksanaan pelayanan tersebut pemerintah sebagai penyelenggara layanan berkewajiban menyusun, menetapkan dan melaksanakan standar dan maklumat layanan, menyediakan sarana, prasarana dan/atau fasilitas pelayanan publik, memberikan pelayanan yang berkualitas, membantu masyarakat dalam memahami hak dan tanggungjawabnya serta bertanggungjawab dalam pelaksanaan pelayanan publik. (Hendri, 2010). Azas kepentingan umum, kepastian hukum, persamaan perlakuan (tidak diskriminatif), keterbukaan, akuntabilitas, kecepatan, kemudahan dan keterjangkauan menjadi syarat mutlak yang harus dipenuhi dalam pelaksanaan pelayanan publik. 
Dwiyanto (2011), mengungkapkan bahwa mendefinisikan pelayanan publik tidak dapat ditentukan hanya dengan melihat lembaga penyelenggaranya (pemerintah dan swasta), atau sumber pembiayaannya semata sebagaimana tertuang dalam UU No.25 Tahun 2010, tetapi dilihat dari karakteristik dan sifat dari pelayanan itu sendiri. Terdapat serangkaian kriteria untuk menentukan jenis pelayanan publik. Pertama, sifat dari barang dan jasa itu sendiri (Stiglitz, 2000; Ostrom, Gradner and Walker, 1994 dalam Dwiyanto, 2011). Barang dan jasa termasuk dalam kategori barang publik atau barang yang memiliki eksternalitas tinggi biasanya tidak dapat diselenggarakan oleh korporasi atau diserahkan kepada pasar. Hal ini karena semua pelayanan tersebut adalah pelayanan yang sangat penting dan harus disediakan oleh negara sehingga pelayanan tersebut seharusnya menjadi bagian dari pelayanan publik. Penyediaan infrastruktur layanan air bersih merupakan bentuk pelayanan publik karena air bersih merupakan kebutuhan penting serta ketersediaan air bersih memberikan dampak eksternalitas yang tinggi terhadap kesehatan, pendidikan dan manfaat sosial (social benefit) lainnya.

Kriteria kedua, untuk mendefinisikan pelayanan publik adalah tujuan dari penyediaan barang dan jasa. Penyediaan barang dan jasa yang dilakukan untuk mencapai tujuan dan misi negara, walaupun barang dan jasa itu bersifat privat, dapat dikatakan sebagai pelayanan publik. Dalam konteks ini, maka penyediaan infrastruktur layanan air bersih bagi masyarakat merupakan bentuk pelayanan publik karena menyangkut kebutuhan masyarakat umum, memiliki keterkaitan dengan kesehatan seseorang serta merupakan hak dasar bagi warga negara sebagaimana diakui dalam konstitusi negara. Dengan demikian, pelayanan publik dapat disimpulkan bahwa sebuah kegiatan pelayanan yang menyangkut hajat hidup orang banyak, kebutuhan kolektif dan menjadi bagian dari komitmen pemerintah untuk memenuhi kebutuhan minimal warganya agar dapat hidup secara layak.

\section{Konsep Kemiskinan}

Setidaknya terdapat dua paradigma mengenai kemiskinan yakni paradigma neoliberal dan sosial demokrat yang memandang kemiskinan dari kacamata stuktural dan individual. Pandangan ini kemudian menjadi basis dalam menganalisis kemiskinan maupun merumuskan kebijakan dan program-program anti kemiskinan. Teori neoliberal yang berakar pada karya klasik oleh Thomas Hobbes, John Lock dan John Stuart Mill yang menyerukan bahwa komponen penting dari sebuah masyarakat adalah kebebasan individu. Secara garis besar, para pendukung neo-liberal berargumen bahwa kemiskinan merupakan persoalan individual yang disebabkan oleh kelemahankelemahan dan/atau pilihan-pilihan individu yang bersangkutan (kemiskinan absolut). Kemiskinan akan hilang dengan sendirinya jika kekuatan pasar diperluas sebesarbesarnya dan pertumbuhan ekonomi dipacu setinggi-tingginya. Secara langsung, strategi penanggulangan kemiskinan harus bersifat "residual", sementara dan hanya melibatkan keluarga, kelompok swadaya atau lembaga keagamaan sehingga negara boleh melakukan intervensi jika peran lembaga diatas tidak mampu lagi menjalankan tugasnya. (Suharto, 2014).

Keyakinan yang berlebihan terhadap keunggulan mekanisme pasar dan pertumbuhan ekonomi secara alamiah dianggap mampu mengatasi kemiskinan dan ketidakadilan sosial mendapat kritik dari kaum sosial demokrat. Teori sosial demokrat memandang bahwa kemiskinan bukanlah persoalan individual, melainkan struktural. 
Kemiskinan disebabkan oleh adanya ketidakadilan dan ketimpangan dalam masyarakat akibat tersumbatnya akses-akses kelompok tertentu terhadap berbagai sumber-sumber kemasyarakatan (kemiskinan relatif). Pendukung sosial demokrat menyakini bahwa penanganan kemiskinan yang bersifat residual justru tidak efektif, karena efeknya singkat, terbatas dan tidak berwawasan pemberdayaan berkelanjutan. (Suharto, 2014).

Jika mengacu pada formula kemiskinan struktural berdasarkan beberapa konsep ataupun pendapat yang dikemukakan diatas, Suharto (2014) mengklasifikasi tingkatan kemiskinan antara lain:

1. Kelompok yang paling miskin (destitute) yang juga sering disebut sebagai fakir miskin. Kelompok ini secara absolut memiliki pendapatan dibawah garis kemiskinan (umumnya tidak memiliki sumber pendapatan sama sekali) serta tidak memiliki akses terhadap berbagai pelayanan dasar.

2. Kelompok miskin (poor). Kelompok ini memiliki pendapatan dibawah garis kemiskinan, namun secara relatif memiliki akses terhadap pelayanan dasar tertentu.

3. Kelompok rentan (vulnerable). Kelompok ini dapat dikategorikan bebas dari kemiskinan, karena memiliki kehidupan yang relatif lebih baik ketimbang kelompok destitute maupun poor. Namun sebenarnya kelompok yang sering disebut near poor (agak miskin) ini masih rentan terhadap perubahan kondisi perekonomian ataupun perubahan sosial disekitarnya.

Jika mengacu pada tingkatan kemiskinan yang dikemukakan diatas, maka keterbatasan akses terhadap pelayanan air bersih yang dialami oleh seseorang dikategorikan sebagai kelompok miskin (poor). Pendapatan yang dimiliki tidak mencukupi untuk memenuhi kebutuhan air bersih ataupun layanan air bersih yang tersedia tidak dapat dinikmati oleh mereka yang berpendapatan rendah.

Keberadaan air bersih sebagai kebutuhan dasar masyarakat yang tidak dapat diakses oleh penduduk mengakibatkan standar hidup menjadi semakin menurun. Keterbatasan akses terhadap air bersih sistem perpipaan yang disediakan oleh pemerintah daerah menyebabkan sebagian besar penduduk miskin bergantung pada pedagang air keliling (water vendor) dan sebagian kecil menggunakan sarana air kran umum (public tap) untuk mendapatkan air bersih. (Utama, 2010). Sekalipun biaya air dari water vendor umumnya lebih mahal dibandingkan air PAM, namun mereka tetap membelinya karena alasan menghemat waktu dan mereka bisa mengerjakan pekerjaan lain yang mungkin lebih tinggi hasilnya dibanding biaya air bersih tersebut. Sekalipun demikian, tentu tidak dapat dipungkiri tetap adanya keluarga yang sangat miskin dan tidak mampu membayar water vendor sehingga terpaksa menggunakan sumber-sumber gratis namun tidak higienis.

\section{Kebijakan Pro poor}

Kebijakan pembangunan ekonomi yang "pro-poor" awalnya didasari pada kegagalan pendekatan pro-growth dan diinisiasi untuk menyediakan perlindungan sosial (social safety net) bagi kelompok masyarakat miskin (poor) yang tidak terjangkau melalui kebijakan pro-pertumbuhan atau kelompok masyarakat yang termarjinalkan dalam proses pembangunan ekonomi. Secara makro, kebijakan pembangunan lebih diarahkan pada proses stabilisasi (sering dikenal sebagai kebijakan stabilisasi menuju pertumbuhan) dengan menargetkan kelompok masyarakat miskin dan marjinal agar dampak negatif dari pertumbuhan ekonomi dapat diperkecil. Pendekatan ini pun 
mengalami kegagalan karena persebaran pertumbuhan ekonomi juga tidak merata dan stabil. Karena itu, muncul kesadaran untuk secara eksplisit menargetkan pertumbuhan kesempatan kerja dan peningkatan pendapatan bagi kelompok masyarakat miskin sebagai tujuan utama dari kebijakan pembangunan ekonomi. Kebijakan model ini dikenal sebagai kebijakan pro poor, yang lebih menyentuh aspek penyebab kemiskinan di berbagai level masyarakat.

Mirzakhanyan dkk (2005) dalam laporan hasil penelitian UNICEF (2012) mendefinisikan kebijakan pro poor sebagai kebijakan yang dikembangkan dan diimplementasikan oleh pemerintah yang mengadopsi pendekatan pembangunan manusia (human development) yang tujuan utamanya adalah untuk memperkuat sumberdaya modal manusia (human capital strengthening) dan mengembangkan kesempatan (expanding opportunities) dari kelompok miskin. Definisi lain dari kebijakan pro-poor dikembangkan oleh Korayem (2004) dalam kajiannya tentang kebijakan pro-poor di Mesir menjelaskan bahwa kebijakan pro-poor dapat dibagi menjadi tiga jenis menurut target dan jenis intervensinya kepada kelompok miskin: (1) kebijakan/program yang spesifik menargetkan penyebab-penyebab kemiskinan atau penerima manfaat utamanya adalah kelompok miskin; (2) kebijakan/program yang meningkatkan kondisi kehidupan kelompok miskin melalui penyediaan infrastruktur dasar dan infrastruktur pendukung perekonomian; (3) kebijakan/program yang menargetkan penurunan biaya hidup bagi kelompok miskin.

El Ouardighi dan Somun-Kapetanovic (2010) dalam kajiannya tentang kebijakan pro-poor di negara-negara Balkan mendefisinikan dan memetakan kebijakan pro-poor dengan meninjau berbagai pandangan tentang kebijakan pro poor. Pertama, kebijakan pro poor adalah kebijakan yang meningkatkan pertumbuhan ekonomi di mana pertumbuhan ekonomi tersebut dapat mengurangi angka kemiskinan. Definisi ini dianggap sangat lemah, karena jika pertumbuhan ekonomi diikuti dengan meningkatnya ketidakmerataan, maka pertumbuhan ekonomi justru menimbulkan gap kemiskinan yang semakin dalam. Kedua, seperti yang didukung oleh Klasen (2008) dan Duclos (2009), kebijakan yang didorong melalui pertumbuhan ekonomi digolongkan pro-poor jika pertumbuhan ekonomi menimbulkan pertumbuhan rata-rata pendapatan kelompok miskin yang lebih besar dibandingkan dengan pertumbuhan rata-rata pendapatan kelompok yang bukan miskin. Hasil penelitiannya menunjukkan bahwa di negara-negara yang mengalami tingkat pertumbuhan ekonomi yang baik selama kurun waktu 19892005 , ternyata tidak diikuti dengan pertumbuhan rata-rata pendapatan kelompok miskin yang tinggi sehingga kebijakan negara-negara tersebut bukan kebijakan pro poor.

Penegasan terkait dengan konsep pro poor juga diungkapkan oleh Araar dkk (2009) berdasarkan riset yang pernah dilakukan terkait dengan kebijakan pro poor di Mexico. Konsep tersebut menggunakan definisi yang didukung oleh Duclos dan Krasen, bahwa kebijakan ekonomi yang mengejar pertumbuhan digolongkan pro poor jika pertumbuhan ekonomi menimbulkan pertumbuhan rata-rata pendapatan kelompok miskin yang lebih besar dibandingkan dengan pertumbuhan rata-rata pendapatan kelompok yang bukan miskin.

Mengacu pada berbagai pendapat di atas dapat disimpulkan bahwa kebijakan pemerintah dikatakan pro-poor ketika manfaat (benefit) yang diperoleh masyarakat miskin atas kebijakan tersebut proporsinya lebih besar dibandingkan dengan manfaat yang diperoleh masyarakat yang tidak miskin (kaya). Jika dikaitkan dengan kebijakan 
pengelolaan dan penyediaan air bersih, maka penyediaan air bersih yang pro-poor ditandai dengan meningkatnya manfaat yang dirasakan oleh penduduk miskin atas keberadaan infrastruktur air bersih yang disediakan oleh pemerintah ataupun proporsi masyarakat miskin yang menikmati air bersih relatif bertambah. Oleh karenanya proses kebijakan yang pro-poor dapat dilihat sebagai proses yang melibatkan kelompok miskin, maupun kebijakan yang meskipun tidak melibatkan kelompok miskin, namun secara langsung mempengaruhi kehidupan mereka.

\section{METODE PENELITIAN}

Penelitian ini merupakan metode studi kasus yang menekankan pendekatan positivist, untuk mengeksplorasi kinerja pelayanan publik yang pro poor dalam penyediaan air bersih oleh PDAM di Sulawesi Tenggara. Penelitian ini dilaksanakan di Sulawesi Tenggara yang difokuskan pada 1 (satu) wilayah kota dan 1 (satu) wilayah kabupaten yaitu Kota Kendari dan Kabupaten Kolaka. Obyek yang diteliti adalah penyedia dan pengguna layanan PDAM kategori rumah tangga. Penelitian dilaksanakan pada Bulan Mei sampai November 2017, Dalam studi ini pengumpulan data dilakukan melalui dua cara, yaitu pengumpukan data primer dan data sekunder dengan teknik pengumpulan data dilakukan dengan cara observasi langsung, dokumentasi (document records) dan wawancara. Populasi dalam penelitian ini terdiri dari pengguna layanan dan penyedia layanan PDAM Kota Kendari dan Kabupaten Kolaka. Adapun sampel penelitian untuk pengguna layanan yaitu pelanggan PDAM Kota Kendari dan Kabupaten Kolaka golongan rumah tangga yang mengkonsumsi air pada kategori Blok I (0-20 $\left.\mathrm{M}^{3}\right)$, dimana blok konsumsi tersebut merupakan kelompok pelanggan yang mengkonsumsi air sesuai standar kebutuhan pokok serta struktur tarif yang kenakan lebih rendah dibandingkan dengan blok konsumsi lainnya. Analisis data dilakukan dengan metode deskriptif kuantitatif dan metode Partial Least Square (PLS).

\section{HASIL DAN PEMBAHASAN}

Sumber perolehan air minum yang berasal dari sumur dan mata air masih mendominasi dipergunakan oleh penduduk Sulawesi Tenggara, sedangkan sumber air minum yang berasal dari ledeng (air perpipaan) masih relatif kecil. Jika dicermati berdasarkan kategori pendapatan penduduk, kelompok penduduk kategori 1/ penduduk miskin (poor) yang menggunakan ledeng (air perpipaan) sebagai sumber air minum masih relatif rendah yakni hanya mencapai $2,45 \%$. Adapun proporsi penduduk Sulawesi Tenggara yang memiliki pendapatan kategori 2,3 dan 4 (pendapatan menengah keatas) lebih banyak mengkonsumsi minum yang berasal dari ledeng. Hal ini mengindikasikan bahwa pada proporsi penggunaan air minum ledeng (perpipaan) oleh penduduk miskin masih relatif rendah jika dibandingkan dengan penduduk yang berpendapatan menengah keatas. Artinya manfaat yang didapatkan oleh penduduk miskin (poor) atas keberadaan infrastruktur air perpipaan masih kecil. Dengan demikian secara umum dapat disimpulkan bahwa pengelolaan air perpipaan belum mengutamakan kelompok penduduk miskin di Sulawesi Tenggara.

Fakta empiris lain yang diperoleh diketahui bahwa secara umum pelanggan yang sudah lama mengkonsumsi air PDAM menyatakan bahwa sekalipun pemerintah daerah 
telah melakukan penyertaan modal ke PDAM serta adanya penyesuaian struktur tarif namun biaya dan waktu perolehan masih menjadi persoalan dalam menikmati layanan air bersih. Persoalan tersebut antara lain pengenaan tarif air PDAM tidak sebanding dengan kualitas dan kontinuitas air serta harga air PDAM cenderung lebih mahal dibandingkan dengan air non PDAM sehingga proporsi pendapatan yang dialokasikan untuk memperoleh air PDAM juga dirasakan relatif besar. Uraian kondisi pembiayaan melalui tarif PDAM di Sulawesi Tenggara dapat dicermati pada boks 5.10 diatas.

Selain tarif, biaya sambungan baru untuk memperoleh air yang disediakan oleh PDAM relatif mahal dengan sistem "pembayaran dimuka" secara tunai. Kondisi pembiayaan infrastruktur berupa kemampuan keuangan yang baik ataupun adanya beban keuangan secara empiris tidak langsung mempengaruhi nilai biaya sambungan. Akibatnya sebagian masyarakat cenderung mengeluarkan biaya yang lebih tinggi untuk menikmati air bersih PDAM yang berkualitas jika dibandingkan biaya perolehan air bersih non PDAM. Ditengarai, biaya sambungan yang masih tinggi serta sistem pembayaran tunai menjadi penyebab semakin berkurangnya keinginan masyarakat untuk menjadi pelanggan PDAM. Fakta di atas menunjukkan bahwa adanya persoalan keterjangkauan pelayanan yang tidak pro poor.

Penegasan terhadap adanya persoalan akses dalam pelayanan yang tidak pro poor juga ditemukan dalam penelitian ini. Waktu yang digunakan rumah tangga pengguna untuk memperoleh air bersih cukup lama (rata-rata air diperoleh 1 kali dalam 2 hari) sehingga terdapat kecenderungan bahwa perolehan air bersih non PDAM lebih mudah diakses dibandingkan air bersih PDAM. Pada sisi yang lain, media penyampaian pengaduan/keluhan pelanggan masih belum tersedia secara mudah dan murah untuk dapat diakses oleh pelanggan. Kedua faktor tersebut menjadi faktor yang dominan mempengaruhi menurunnya jumlah pelanggan PDAM dari tahun ke tahun. Atas berbagai temuan penelitian ini membuktikan bahwa pembiayaan terhadap infrastruktur utama maupun infrastruktur pendukung PDAM tidak langsung memperbaiki akses dan keterjangkauan pelayanan ataupun meningkatkan manfaat bagi pelanggan rumah tangga, tetapi berpengaruh terhadap kinerja pelayanan secara langsung. Pembiayaan infrastruktur akan mampu menghasilkan pelayanan yang pro poor apabila terjadi peningkatan kinerja pelayanan yang dilakukan oleh PDAM itu sendiri terutama yang terkait dengan kualitas layanan (teknis dan non teknis) dan cakupan pelayanan.

Hasil temuan ini mengembangkan hasil penelitian yang dilakukan oleh Walker dkk (2000) yang menyatakan bahwa meskipun harga rendah sudah diterapkan dalam pengenaan tarif air yang disediakan oleh pemerintah daerah (PDAM) dan dikatakan bermanfaat terutama bagi penduduk berpendapatan rendah/miskin, namun dalam kenyataannya tidak membantu penduduk miskin karena cakupan pelayanan terhadap mereka masih terbatas yang mengakibatkan harus mencari sumber lain dengan harga yang jauh lebih mahal. Artinya pengelolaan dan penyediaan air perpipaan yang pro poor tidak dapat dilakukan hanya dengan penentuan tarif rendah ataupun subsidi tarif tetapi yang lebih penting adalah perbaikan kinerja pelayanan PDAM sebagai operator penyedia layanan air bersih bagi masyarakat.

Adanya pemisahan fungsi kepemilikan dan manajemen perusahaan menunjukkan bahwa penyediaan air bersih oleh pemerintah daerah yang dikelola Perusahaan Daerah Air Minum (PDAM) merupakan praktek corporate governance. Penyerahan kegiatan pengelolaan dan pelayanan air bersih cenderung berimplikasi terhadap munculnya 
benturan kepentingan antara pemerintah daerah (sebagai prinsipal) dan PDAM (sebagai agen) yaitu kepentingan pemenuhan kebutuhan publik (public interest) dan kepentingan bisnis (profit interest). Dengan demikian praktek corporate governance dalam penyediaan layanan air bersih akan memiliki pengaruh terhadap kinerja pelayanan air bersih bagi masyarakat (publik). Hal ini memperkuat teori keagenan (agency theory) oleh Jensen and Mekling (1976) yang menyatakan bahwa praktek principal agen akan berpeluang menimbulkan terjadinya moral hazard dan adverse selection yang akan menimbulkan sejumlah implikasi serius bagi kinerja dan sustainabilitas perusahaan. Artinya terdapat kecenderungan pengelolaan dan penyediaan air bersih yang dilakukan melalui PDAM lebih mengutamakan kepentingan bisnis, mengabaikan pemenuhan kebutuhan publik, atau cenderung mengabaikan prinsip-prinsip corporate governance sesuai dengan peraturan dan tujuan perusahaan yang telah ditetapkan.

Penerapan prinsip corporate governance yang baik dalam pengelolaan dan penyediaan air bersih dapat meminimalkan potensi kecurangan akibat agency problem tersebut, namun jika prinsip tersebut diabaikan oleh agen maka kinerja pelayanan publik yang merupakan kepentingan principal tidak akan membaik. Hal ini sejalan dengan temuan Priyanto (2014) yang menyatakan bahwa penerapan yang konsisten terhadap prinsip corporate governance dalam pengelolaan air bersih oleh PDAM menjadi piranti utama untuk meminimalkan agency problem, dimana corporate governance dapat digunakan oleh "board" untuk mengarahkan, mengendalikan serta mengawasi pengelolaan sumber daya perusahaan secara efisien, efektif, ekonomis dan produktif sehingga keberadaan perusahaan daerah sebagai operator penyedia layanan air bersih bagi masyarakat (pelayanan publik) dapat terpenuhi.

Fakta empiris menunjukkan bahwa penerapan prinsip corporate governance khususnya prinsip akuntabilitas (accountability) menurut penilaian rumah tangga pelanggan PDAM adalah indikator yang paling penting menentukan tata kelola perusahaan yang baik (good corporate governance) dalam pengelolaan dan penyediaan air bersih, sedangkan berdasarkan hasil pengujian model pengukuran (koefisien outer loading) menunjukkan bahwa keseriusan perusahaan untuk mewujudkan tercapainya tujuan organisasi PDAM merupakan indikator yang paling kuat dalam menentukan pencapaian tata kelola perusahaan yang baik (good corporate governance) dalam pengelolaan dan penyediaan air bersih.

Pentingnya prinsip akuntabilitas merupakan cerminan bahwa praktek corporate governance membutuhkan pertanggungjawaban hukum para direksi PDAM dalam menjalin hubungan yang berbasis kepercayaan (trust) dengan pemerintah daerah maupun pelanggan. Setiap tindakan, keputusan dan kebijakan yang ditempuh oleh PDAM harus sesuai dengan pedoman strategis perusahaan, tidak boleh adanya kepentingan pribadi dalam pengelolaan dan penyediaan layanan air bersih. Rumah tangga pelanggan menilai bahwa prinsip akuntabilitas menjadi acuan utama PDAM (agen) agar kepentingan principal (pemerintah daerah dan pelanggan) tidak terabaikan.

Penegasan terhadap pencapaian tujuan organisasi bagi PDAM juga menjadi bagian penting dalam membentuk tata kelola perusahaan yang baik (good corporate governance). Perusahaan publik yang dikelola oleh swasta memerlukan tata kelola yang in line with tujuan organisasi yakni penyediaan air bersih yang dapat dijangkau oleh masyarakat sekaligus adanya keuntungan dalam operasional perusahaan. Artinya pengelolaan dan penyediaan air bersih tidak hanya mengedepankan keuntungan 
perusahaan (misi bisnis), tetapi perlunya keseriusan PDAM menyediakan air bersih yang berkualitas, merata dan terjangkau bagi masyarakat (misi publik).

Temuan penelitian yang menekankan prinsip akuntabilitas maupun keseriusan PDAM dalam menegakkan tujuan perusahaan (misi publik dan misi bisnis) dalam pengelolaan dan penyediaan air bersih akan berdampak terhadap kinerja pelayanan PDAM terutama yang terkait dengan tingkat penggunaan (utilization) air, kualitas pelayanan, cakupan pelayanan serta adanya kepuasan rumah tangga pelanggan dalam memperoleh air bersih. Oleh karenanya PDAM yang tidak akuntabel akan diperhadapkan pada kinerja pelayanan publik yang menurun sehingga membangun image publik "tidak profesional", adanya distrust dan bahkan mendorong keinginan masyarakat untuk menyediakan air bersih secara individual.

Fakta empiris menunjukkan bahwa penerapan prinsip akuntabilitas merupakan prinsip yang paling penting menurut penilaian pelanggan PDAM. Penilaian ini menegaskan bahwa pengelolaan dan penyediaan air bersih yang dilakukan PDAM memerlukan kejelasan fungsi, struktur, sistem dan pertanggung jawaban oleh masingmasing organ yang terlibat dalam PDAM. Pelanggan menilai bahwa terkadang pemerintah daerah (pemilik) tidak melakukan pengawasan secara maksimal terhadap kegiatan pelayanan PDAM sehingga fungsi pengawasan cenderung mandul. Oleh karenanya prinsip akuntabilitas menjadi penting dalam menciptakan tata kelola PDAM yang baik (good corporate governance). Pada sisi yang lain, pelanggan menilai bahwa dimensi keterjangkauan merupakan indikator yang paling penting untuk menghasilkan pelayanan publik yang pro poor. Dimensi keterjangkauan ditekankan pada aspek biaya perolehan air bersih, baik biaya sambungan, tarif air maupun harga air PDAM dibandingkan dengan air non PDAM. Hal ini menunjukkan bahwa pelayanan air bersih dikatakan pro poor apabila rumah tangga pelanggan mengeluarkan proporsi pendapatan relatif lebih rendah dalam menikmati air bersih PDAM dibandingkan dengan proporsi pengeluaran untuk memperoleh air bersih non PDAM. Dengan kata lain manfaat yang diperoleh rumah tangga pelanggan lebih besar dalam memperoleh layanan PDAM jika dibandingkan dengan pelanggan kategori non rumah tangga.

Fakta-fakta empiris yang telah dikemukakan juga menjadi penegasan bahwa sekalipun pengelolaan dan pelayanan air bersih tidak akuntabel, namun tidak secara langsung akan menurunkan akses dan keterjangkauan pelayanan bagi rumah tangga pelanggan, akan tetapi pengelolaan yang tidak akuntabel justru memperburuk kinerja pelayanan PDAM yang selanjutnya berimplikasi pada akses dan keterjangkauan pelayanan. Sebaliknya, adanya akuntabilitas dalam pengelolaan dan penyediaan air bersih justru akan meningkatkan tingkat penggunaan (utilization) pelayanan, perluasan cakupan pelayanan (coverage area) serta adanya kepuasan pelanggan baik dari aspek teknis (kualitas air) maupun non teknis (fasilitas infrastruktur dan kemampuan teknis pelayanan) sehingga berdampak terhadap perolehan air yang mudah, murah, terjangkau dan berkualitas bagi masyarakat.

Selain itu, adanya penerapan prinsip corporate governance yang masih memburuk khususnya prinsip responsibilitas, kewajaran dan independensi juga berimplikasi secara tidak langsung terhadap pelayanan yang pro poor, namun berpengaruh langsung terhadap kinerja pelayanan sebagaimana yang telah dikemukakan pada bagian sebelumnya. Fakta empiris menunjukkan bahwa penyerahan kewenangan pengelolaan dan penyediaan air bersih kepada perusahaan daerah (PDAM) yang tidak disertai dengan penerapan prinsip- 
prinsip tersebut menyebabkan perusahaan lebih mengutamakan kepentingannya sebagai corporate, yang artinya berpengaruh terhadap tingkat penggunaan (utilization) air bersih PDAM, cakupan (coverage area) pelayanan serta kepuasan rumah tangga pengguna (user) layanan, yang selanjutnya akan berdampak terhadap akses dan keterjangkauan pelayanan. Rumah tangga pelanggan mengungkapkan bahwa kebijakan tata kelola PDAM yang masih mengabaikan beberapa prinsip corporate governance akan memunculkan kebijakan yang cenderung mengabaikan kepentingan pelanggan kategori rumah tangga terutama yang berpendapatan rendah. PDAM yang diperhadapkan pada tata kelola (corporate governance) yang buruk menunjukkan bahwa kewenangan pengelolaan air bersih yang dilakukan oleh PDAM cenderung tidak profesional sebagai entitas penyedia layanan publik. Temuan ini mempertegas hasil penelitian Godrey et. al (1997) yang mengungkapkan bahwa dalam teori keagenan sektor publik, tidak ada jaminan bagi agen untuk bertindak dalam memenuhi kepentingan principal ataupun untuk kesejahteraan masyarakat (publik) tetapi cenderung memiliki perilaku oportunis.

Fakta empiris juga diperoleh bahwa pelayanan yang dilakukan PAM khususnya pegawai belum sepenuhnya memberikan perlakuan yang sama kepada pelanggan terutama dalam hal penanganan keluhan berdasarkan standar pelayanan ataupun peraturan yang berlaku. Hal ini diperkuat dari hasil penelitian yang menunjukkan bahwa nilai loading factor yang paling rendah adalah pada dimensi penerapan prinsip independensi. Artinya penyediaan air bersih yang dilakukan PDAM belum independen, mengedepankan kepentingan corporate sebagai entitas bisnis terutama pada saat pelayanan pemasangan sambungan baru dan penanganan pengaduan pelanggan. Demikian pula jika dilihat dari nilai mean diketahui bahwa pelanggan pada umumnya menilai penerapan prinsip responsiblitas dan penerapan prinsip kewajaran (fairness) masih sangat rendah yang berarti kedua prinsip ini belum sepenuhnya mampu membentuk penerapan corporate governance atau pelanggan menilai bahwa pemerintah daerah maupun PDAM masih memiliki tingkat responsibilitas yang rendah serta masih terdapatnya perlakuan yang tidak fair dalam memberikan pelayanan air bersih bagi masyarakat (public service). Dengan demikian pelayanan publik yang dilakukan PDAM dalam mengelola dan menyediakan air bersih yang tidak konsisten terhadap prinsip tata kelola perusahaan yang baik (good corporate governance) menyebabkan PDAM tidak menghasilkan pelayanan publik yang pro poor.

\section{KESIMPULAN}

Hasil penelitian diperloeh bahwa kinerja PDAM di Sulawesi Tenggara dalam melakukan pelayanan publik di pengaruhi oleh kondisi pembiayaan infrastruktur yang dimilkiki serta penerapan terhadap prinsip-prinsip corporate governance dalam mengelola dan menyediakan air bersih perpipaan. Selain itu diperoleh pula bahwa pelayanan publik (public service) yang dilakukan PDAM dalam mengelola dan menyediakan air bersih perpipaan berdampak terhadap pelayanan yang pro poor. Adanya persoalan pada kualitas pelayanan dan cakupan pelayanan berdampak terhadap kemampuan PDAM dalam menghasilkan air bersih perpipaan cenderung tidak pro poor (tidak dapat meningkatkan akses dan keterjangkauan) pelayanan air bersih. Public service PDAM yang baik akan menciptakan terpenuhinya kebutuhan air bersih bagi masyarakat yang mudah, murah dan terjangkau. 


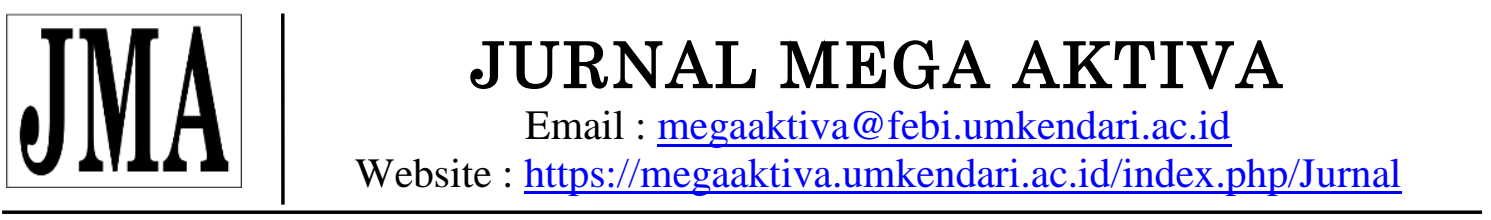

\section{DAFTAR PUSTAKA}

Araar, Abdulkarim et.al, 2009. Testing for Pro-Poorness of Growth, with an Application to Mexico. Review of Income and Wealth, Series 55, No.4, December 2009

Bird, Richard. 2000. Desentralisasi Fiskal di Negara-negara Bekembang. Gramedia. Jakarta.

Creswell, John. W. 2012. Research Design Pendekatan Kualitatif, Kuantitatif dan Mixed. Pustaka Pelajar. Yogyakarta

Dwiyanto, Agus. 2011. Manajemen Pelayanan Publik; Peduli, Inklusif dan Kolaboratif. UGM Press. Yogyakarta

El Ouardighi, Jalal dan Rabija Somun-Kapetanovic, 2009. "Is Growth Pro-Poor in the Balkan Region?" Eastern Europe Economics, Vol. 48 No. 3

Gray., N.F.2000. Drinking Water Quality. Cambridge University Press.

Hadipuro, Wijanto. 2009. Valuasi Air. Amarta Institute-TIFA Foundation. Jakarta

Hakim, D. Lukmanul. 2010. Aksesibilitas Air Bersih Bagi Masyarakat di Permukiman Linduk Kecamatan Pontang Kabupaten Serang. Tesis Program Pascasarjana Universitas Diponegoro. Semarang

Hanafi, Imam. 2011. Kebijakan Air Bersih. UB Press. Malang

Hendri. 2010. Pelayanan Publik Menurut UU No. 25 Tahun 2009. http://lp3si.wordpress.com. April 2014

Howard, G. And Jamie B., 2000. Domestic Water Quantity, Service Level and Health. World Health Organization 2003. http://www.who.int/ water_sanitation_health/diseases/WSH03.02.pdf. Maret 2014

Hyman, David. 2005. Public Finance; Eighth Edition. Thomson SouthWestern. USA

JCV. Pezzey, G.A Mill. 2015. A Review of Tariffs for Public Water Supply, Environmental Agency, UK.

Korayem, Karima. 2004. Pro-Poor Policies in Egypt: Identification and Assessment. International Journal of Political Economy, vol. 32 No.2

Klasen, S. 2008. Economic Growth and Poverty Reduction: Measurement Issues Using Income and Nonincome Indicators. World Development, vol 36 No.3

Mahsun, Moh. 2011. Pengukuran Kinerja Sektor Publik. BPFE UGM Yogyakarta

Matei, Ani and Ciprian Drumasu. 2014. Romanian Public Sector. A Corporate Approach. Procedia - Social and Behavioral Sciences 109 ( 2014 ) 1120-1124

Mungkasa, O. 2007. Dampak Investasi Air Minum Terhadap Pertumbuhan Ekonomi dan Distribusi Pendapatan di DKI Jakarta. http://www.academia.edu. Februari 2014

Pattinasarany, D. 2012. Desentralisasi Fiskal dan Pelayanan Publik. http://www.google.com. Februari 2014

Puspitorini, D dan Masduqi, A. 2012. Strategi Penyediaan Air Bersih di Desa Rawan Air Bersih di Kabupaten Ponorogo Propinsi Jawa Timur. Tesis Program Studi Teknik Prasarana Lingkungan Permukiman Program Pascasarjana Institut Tekhnologi Surabaya

Prawoto, Agus. 2011. Pengantar Keuangan Publik (Edisi Pertama). BPFE- Yogyakarta. Yogyakarta

Rochmah., S. 2013. Responsivitas Pelayanan; Studi pada Kebijakan Pelayanan Air Bersih. UB Press. Malang 


\section{JURNAL MEGA AKTIVA}

Email : megaaktiva@febi.umkendari.ac.id

Website : https://megaaktiva.umkendari.ac.id/index.php/Jurnal

Savenije, Hubert.H.G and Van Der Zaag. 2006. Water As An Economic Good: The Value Of Pricing And The Failure Of Markets. Value of Water Research Report Series No. 19. UNESCO-IHE Institute for Water Education, Delft, the Netherlands

Santoso, H. 2010. Air Bersih dan Sanitasi Sebagai Kebijakan Sosial. Modul Kebijakan Publik. Komunitas Indonesia untuk Demokrasi, Jakarta

Suharto, Edi. 2014. Konsep dan Strategi Pengentasan Kemiskinan Menurut Perspektif Pekerjaan Sosial. http://www.academia.edu. September 2015

Utama, C. 2010. Manajemen Kenaikan Tarif PAM Untuk Peningkatan Akses Air Bersih Bagi Seluruh Masyarakat. Jurnal Administrasi Bisnis-Unpar Vol.6, No.2: hal. 146159

UNICEF. 2012. Kebijakan Pemetaan Pro Rakyat Miskin di Provinsi Aceh. http://www.unicef.org/indonesia/id. September 2015 